\title{
The description of Gyrodactylus corleonis sp. n. and G. neretum sp. n. (Platyhelminthes: Monogenea) with comments on other gyrodactylids parasitising pipefish (Pisces: Syngnathidae)
}

\author{
Giuseppe Paladini ${ }^{1,2}$, Joanne Cable ${ }^{3}$, Maria Letizia Fioravanti ${ }^{2}$, Patricia J. Faria ${ }^{3}$ and Andrew P. Shinn \\ ${ }^{1}$ Institute of Aquaculture, University of Stirling, Stirling, FK9 4LA, Scotland, UK; \\ ${ }^{2}$ Department of Veterinary Public Health and Animal Pathology, Faculty of Veterinary Medicine, University of Bologna, \\ Via Tolara di Sopra 50, 40064 Ozzano dell'Emilia (BO), Italy; \\ ${ }^{3}$ School of Biosciences, Cardiff University, Cardiff, CF10 3AX, UK
}

\begin{abstract}
The current work describes two new species of Gyrodactylus von Nordmann, 1832 collected from pipefish Syngnathus scovelli (Evermann et Kendall) and Syngnathus typhle L. during two separate gyrodactylosis episodes on fish held in a public aquarium located in northern Italy. The gyrodactylids collected from the skin, fins and gills of pipefish were subjected to a morphological analysis of the attachment hooks and the morphometric data were compared to the four species of Gyrodactylus previously described from syngnathid hosts, namely G. eyipayipi Vaughan, Christison, Hansen et Shinn, 2010, G. pisculentus Williams, Kritsky, Dunnigan, Lash et Klein, 2008, G. shorti Holliman, 1963 and G. syngnathi Appleby, 1996. Principal components analysis (PCA) of the morphological data indicated six clusters; two discrete groups among the specimens taken from the pipefish held in the Italian aquarium and four further groups representing G. eyipayipi, G. pisculentus, G. shorti and G. syngnathi. Molecular sequences of the ribosomal internal transcribed spacers (ITS1 and ITS2) and the 5.8S gene for the new species considered here were then compared with those available for other species in GenBank. The comparison did not reveal any identical match, supporting the morphological analysis that Gyrodactylus corleonis sp. n. from S. typhle and Gyrodactylus neretum sp. n. from S. scovelli represent distinct species. Both G. corleonis and G. neretum possess robust hamuli, marginal hook blades that curve smoothly from their sickle base to a point beyond the toe and, ventral bars with a broad median portion and a reduced membrane. Gyrodactylus corleonis, however, can be distinguished on the basis of its heart-shaped ventral bar; G. neretum has a 1:2 hamulus point:shaft ratio and a rectangular-shaped ventral bar. A redescription of the haptoral hard parts of the four species previously recorded on pipefish is also presented.
\end{abstract}

Keywords: Monogenea, Gyrodactylus, Syngnathidae, Syngnathus typhle, Syngnathus scovelli

Over 400 species of Gyrodactylus von Nordmann, 1832 have been described (Harris et al. 2004, 2008) and so far only 4 are known to parasitise syngnathids viz Gyrodactylus eyipayipi Vaughan, Christison, Hansen et Shinn, 2010 from the greater pipefish Syngnathus acus L., Gyrodactylus pisculentus Williams, Kritsky, Dunnigan, Lash et Klein, 2008 from the northern pipefish Syngnathus fuscus Storer, Gyrodactylus shorti Holliman, 1963 from the Gulf pipefish Syngnathus scovelli (Evermann et Kendall) and Gyrodactylus syngnathi Appleby, 1996 from Nilsson's pipefish Syngnathus rostellatus Nilsson.

In the current study, we describe two new species of Gyrodactylus that were recovered from dead and moribund specimens of Syngnathus typhle L. and S. scovelli held in separate exhibits in a public aquarium located in the Emilia-Romagna region in northern Italy. Following the unexpected mortality of pipefish, a sample of ethanol- fixed and moribund specimens were sent to the Laboratory of Fish Pathology of the University of Bologna for diagnostic assessment. On post-mortem examination, both species of pipefish were found to harbour moderate gyrodactylid infections, although a concomitant bacterial infection was diagnosed as the primary cause of death and morbidity.

Pipefish are an attractive addition to public aquaria and yet information relating to their natural parasite fauna, their tolerance to captive conditions and their resilience to disease is largely unknown. This account represents the second occasion where gyrodactylids parasitising syngnathids held under aquarium conditions have been associated with host morbidity and mortality. The only other case regards $S$. fuscus where mortality coincided with high burdens of $G$. pisculentus $(600+$ parasites / host) (Williams et al. 2008). 


\section{MATERIALS AND METHODS}

Specimen collection and preparation. Specimens of moribund pipefish Syngnathus scovelli $(\mathrm{n}=1$; standard length $9 \mathrm{~cm})$ and $S$. typhle $(\mathrm{n}=4$; standard length $20-25 \mathrm{~cm})$ were collected from a pipefish exhibit, where the species were held separately, within a large public aquarium in the Emilia-Romagna region of Italy. Fish were euthanised by an overdose of the anaesthetic MS222 (Sandoz) and then examined immediately in seawater using an Olympus SZ40 dissecting microscope at $\times 4$ magnification. Gyrodactylids were removed using mounted triangular surgical needles (size 16, Barber of Sheffield, UK) and then prepared for morphological and molecular analyses. Individual live specimens were placed on slides and then either prepared as whole mounts or subjected to proteolytic digestion. Whole mounts were flattened in $3 \mu 1$ distilled water using $18 \times 18 \mathrm{~mm}$, "0" thickness coverslips (VWR International, Lutterworth, UK). The specimens were then cleared and fixed in situ through the addition of $3 \mu \mathrm{l}$ ammonium picrate glycerine to the edge of the coverslip. Each parasite was processed individually, its haptor was removed, placed on a glass slide and the tissues enclosing the attachment hooks removed using the proteinase K-based method detailed in Paladini et al. (2009a) i.e. $3 \mu \mathrm{l}$ of digestion solution $(100 \mu \mathrm{g} / \mathrm{ml}$ proteinase K (Cat. No. 4031-1, Clontech UK Ltd., Basingstoke, UK), 75 mM Tris-HCl (Sigma-Aldrich, Poole, UK), 10 mM EDTA (Sigma-Aldrich), 5\% SDS (SigmaAldrich)) added to each haptor. Digestion of each specimen was continuously monitored under a $\times 4$ objective on an Olympus SZ30 dissecting microscope. Tissue digestion was arrested when the hooks were suitably flattened and they were mounted in situ by the addition of $2 \mu \mathrm{l}$ of a 1:1 formaldehyde : $100 \%$ glycerine mix. The edges of the coverslip were then sealed using nail varnish. Additional specimens of each Gyrodactylus species were digested on $11 \mathrm{~mm}$ round glass coverslips, sputter-coated with gold and then examined using a JEOL JSM5200 scanning electron microscope operating at an accelerating voltage of $25 \mathrm{kV}$.

Morphological analysis. The haptoral hard parts were drawn at magnifications of $\times 40$ and $\times 100$ oil immersion from images captured using MRGrab 1.0.0.4 (Carl Zeiss Vision GmbH, 2001) software and a Zeiss AxioCam MRc digital camera mounted on an Olympus BX51 compound microscope using a $\times 0.75$ interfacing lens. For each specimen, 27 point-to-point morphometric measurements were made on the haptoral hooks from images captured using a JVC KY-F30B 3CCD video camera mounted on an Olympus $\mathrm{BH} 2$ microscope with phase contrast using a 2.5 interfacing lens at $\times 100$ oil immersion and KS300 (ver. 3.0) (Carl Zeiss Vision GmbH, 1997) image analysis software. These measurements (as described by Shinn et al. 2004) are given in micrometres as the mean \pm standard deviation followed by the range in parentheses, unless otherwise stated. Type materials of each new species are deposited in the Institute of Parasitology, Biology Centre of the Academy of Sciences of the Czech Republic, České Budějovice, Czech Republic (IPCAS), in the Parasitic Worms Division, The Natural History Museum, London, UK (BMNH), and in the Australian Helminthological Collection (AHC) of The South Australian Museum (SAMA), North Terrace, Adelaide. Fifteen paratypes of G. pisculentus from S. fuscus (Acc. Nos. BMNH 2008.4.8.1-10 and USNPC 100699), the holotype and two paratypes of $G$. shorti from S. scovelli (Acc. No. USNPC Helm. Coll. No. 59597) from USDA U.S.
National Parasite Collection, Beltsville, Maryland, USA, and two paratypes of G. syngnathi from S. rostellatus (BMNH Reg. No. 1995.9.7.2-4) were re-examined for the current study. In addition, eight formalin-fixed specimens of $G$. pisculentus from $S$. fuscus donated by Prof. D. Kritsky (Idaho State University, Pocatello, USA) and five voucher specimens of G. eyipayipi from $S$. acus fixed in $80 \%$ ethanol donated by Dr. K. Christison (Department of Environmental Affairs and Tourism, Marine and Coastal Management, Roggebaai, South Africa), were subjected to proteolytic digestion for morphological studies.

Molecular analysis. Sequences of the internal transcribed spacer (ITS) region 1, ITS 2 and 5.8S ribosomal gene were obtained using primers P3b (Cable et al. 2005) and P4 (Cable et al. 1999) following the conditions described in Paladini et al. (2009b). The primer combination (P3b + P4) failed to generate any amplicon for Gyrodactylus specimens from $S$. scovelli, therefore another 8 primers were tested, in a total of 11 different combinations: ITS1A, ITS2, ITS4.5 (Matějusová et al. 2001), ITS2R, ITS1R (Ziętara et al. 2002), ITS1 (Cunningham 1997), R1, F3 and R3 (Cable et al. 1999). Finally, an amplicon of 550 bp was generated using ITS2 and ITS4.5.

Sequences were aligned using CLUSTAL X (Jeanmougin et al. 1998) and hypervariable regions of the ITS1 and ITS2 were deleted following the criteria of Matějusová et al. (2003) by comparing our alignment with EMBLALIGN: Align_000605 (available at http://srs.ebi.ac.uk/srsbin/cgi-bin/wgetz?id+1tUKC1WsOD6+-e+EMBLALIGN:'ALIGN_000605'). Analyses were conducted following the criteria of Ziętara et al. (2002) by initially separating groups based on 5.8S and subsequently using the spacers for species identification by comparing within the group formed by analysis of 5.8S. Sequences from the ITS2 were aligned and compared with GenBank sequences of Gyrodactylus anguillae Ergens, 1960 (AB063294); G. cf. micropsi Gläser, 1974 (AJ427221); G. kobayashii Hukuda, 1940 (AF484534); G. longidactylus Geets, Malmberg et Ollevier, 1998 (AY338449); G. rugiensis Gläser, 1974 (AF328870); G. rugiensoides Huyse et Volckaert, 2002 (AJ427414); G. salaris Malmberg, 1957 (AF328871), G. sprostonae Ling, 1962 (AY278044) and G. eyipayipi (FJ040183). Neighbour-Joining trees were created with $371 \mathrm{bp}$ of the $5.8 \mathrm{~S}$ and ITS2 using MEGA4 (Tamura et al. 2007).

Principal Components Analysis (PCA). Morphological examination of the specimens in the current study suggested that there were two different species present, which were not only similar to one another but also to those of G. eyipayipi, G. pisculentus, G. shorti and G. syngnathi, previously described from pipefish. PCAs, therefore, were performed on the haptoral measurements from each specimen using the multivariate analysis package Statistica '99 Edition (StatSoft Inc., Tulsa, OK, USA) to ascertain whether any sub-structuring within the data was indicative of more than one species. The variables used for this analysis included $22 \mathrm{Ln}$-transformed point-to-point measurements listed in Table 1. Structures with a coefficient of variation (CV) of $>10 \%$, i.e. the dorsal bar length (DBL) and width (DBW), which have been shown to be consistently unreliable in previous studies (Shinn et al. 1996), were excluded along with structures with high CVs determined in this analysis, i.e. the hamulus inner curve length (HICL), the hamulus point curve angle $\left(\mathrm{HPCA}^{\circ}\right)$ and the inner hamulus aperture angle $\left(\mathrm{IHAA}^{\circ}\right)$. 


\section{RESULTS}

The examination of the moribund pipefish in this study revealed that the single specimen of Syngnathus scovelli was parasitised by $\sim 40$ gyrodactylids representing a single species, while the four specimens of $S$. typhle were infected with a second morphologically different species ( $\sim 10$ gyrodactylids per host). All gyrodactylids were collected from the body surface, the fins and the gills of both pipefish species, the majority being on the gills. No gyrodactylids were encountered within the brood pouch of either species. A principal components analysis of the morphometric data collected from the current material and the four known gyrodactylid species parasitising syngnathid hosts revealed six discrete clusters (Fig. 6). Specimens were separated principally on the overall length of their haptoral hard structures along Factor 1 and by the size of the hamulus aperture length (HA), hamulus aperture angle $\left(\mathrm{HAA}^{\circ}\right)$ and the distal width of the marginal hook sickle (MHSiDW) (Fig. 6, Table 2). The gyrodactylids collected from $S$. typhle possessed the largest haptoral structures of all the gyrodactylids considered in the study, while the new specimens collected from $S$. scovelli were clearly separated from $G$. shorti, which was described from the same host (Holliman 1963) and represents the species with the smallest sized haptoral hard parts (see Table 1).

We propose the name Gyrodactylus corleonis sp. n. for the species of Gyrodactylus collected from S. typhle and Gyrodactylus neretum sp. n. for the species found to infect $S$. scovelli. These two species of Gyrodactylus are described and compared with the other four species parasitising syngnathids.

\section{Gyrodactylus corleonis sp. n.}

Fig. 1, Table 1

Morphological description. Body elongate, 817 (690907) long, 223 (192-263) wide. Anterior pharyngeal bulb 41.2 (38.4-42.3) long, 58.7 (52.3-68.0) wide; posterior pharyngeal bulb 40.3 (32.4-47.0) long, 79.5 (52.9-120.4) wide. Seven to nine pharyngeal processes 25.5-31.3 long. Intestinal crura extending beyond the posterior edge of testes. Haptor ovate, 108.8 (98.9-120.2) long $\times$ 169.1 (143.8-234.0) wide. Male copulatory organ (MCO) spherical, 23.2 (19.6-30.4) long $\times 23.2$ (19.9-29.0) wide armed with one principal spine and 10-13 small spines in a single row, the outer 4-6 larger than the inner 4-7. MCO position variable, usually medial, posterior to the posterior pharyngeal bulb. Hamuli stout, 56.0 (54.1-58.3) total length; hamulus shaft length 32.7 (31.4-33.7); hamulus point 26.5 (25.6-28.2) long, arises at angle of $51.3^{\circ}$ $\left(47.9-56.2^{\circ}\right)$ (internal measurement) to the shaft of hamulus; hamulus root 19.5 (17.7-20.6) long. Dorsal bar attachment points on hamuli, pronounced and rhomboid in dimensions, 12.1 (11.1-14.0) long. Dorsal bar simple, 24.9 (22.8-27.0) long, 3.0 (2.5-3.8) wide. Ventral bar cordate, 23.2 (21.9-24.8) long, 21.6 (20.2-23.6) wide; ventral bar processes small $0.5(0.2-1.2)$ long; ventral bar membrane short, approximately rhomboid with a gently rounded distal edge, 10.7 (8.3-14.0) long. Total length of marginal hooks 33.1 (31.2-35.2); marginal hook shaft 26.2 (24.9-27.7) long; marginal hook sickle proper 7.1 (6.7-8.3) long. Shaft and point regions of sickle curve smoothly and taper to a fine tip far beyond the toe. Sickle distal width 5.9 (5.0-6.4); proximal width 5.9 (5.5-6.2). Aperture of marginal sickle wide, 6.7 (6.1-7.3) long, the inner curve of sickle describing a smooth curve. Toe triangular, 2.9 (2.7-3.1) long; heel deep and rounded.

Type host: Broad-nosed pipefish Syngnathus typhle L. (Syngnathidae, Syngnathiformes).

Collection site: Large public aquarium in the EmiliaRomagna region of Italy. Aquarium records suggest, though not confirmed, that the specimens of $S$. typhle were caught off the French coast near Marseille.

Site of infection: Gills, skin and fins.

Type material: Ten specimens were studied for light microscopy. Holotype (BMNH Reg. No. 2008.12.15.3) and paratype (BMNH Reg. No. 2008.12.15.4) are deposited in the Parasitic Worm Collection at The Natural History Museum, London (BMNH). Additionally, one paratype (M-476) is deposited in the gyrodactylid collection held at the Institute of Parasitology, Biology Centre of the Academy of Sciences of the Czech Republic, České Budějovice (IPCAS), and 7 paratypes (AHC 29829-29835) are deposited in the Australian Helminthological Collection (AHC) of The South Australian Museum (SAMA), North Terrace, Adelaide.

Etymology: Named after the lion (= leonis) heart (= cor) shaped ventral bar.

Molecular sequence data: The fragment of $1119 \mathrm{bp}$ encoding the 18S (18 bp), ITS1 (489 bp), 5.8S (156 bp), ITS2 ( $398 \mathrm{bp}$ ) and 28S (58 bp) is deposited in GenBank under Acc. No. FJ183747.

Molecular characterisation. The ITS1 was categorised as a "short fragment" but unusually, the $5.8 \mathrm{~S}$ sequence was 156 bp (compared to $157 \mathrm{bp}$ for the majority of species; Ziętara and Lumme 2004). ITS1 sequences of G. corleonis presented $85 \%$ identity with $G$. anguillae, $G$. cf. micropsi and G. longidactylus (coverage of 80\%), while $5.8 \mathrm{~S}$ gene presented $100 \%$ identity with G. eyipayipi and $G$. sprostonae, $99.98 \%$ with $G$. neretum and $99 \%$ with G. rugiensis, G. longidactylus, G. cf. micropsi, G. kobayashii and G. anguillae (coverage of 100\%). ITS2 sequences of $G$. corleonis showed $99.97 \%$ identity with $G$. neretum and BLAST searches identified $82 \%$ identity with $G$. anguillae, $80 \%$ with $G$. cf. micropsi, G. longidactylus, G. rugiensoides and G. rugiensis (average coverage of $90 \%$ ). The Neighbour-Joining tree (Fig. 7) using $215 \mathrm{bp}$ of the ITS2 and $156 \mathrm{bp}$ of the $5.8 \mathrm{~S}$ clusters $G$. neretum, G. corleonis and G. eyipayipi together.

Comments. The precise shape of the marginal hook sickle can be seen clearly in specimens prepared for scanning electron microscopy (Fig. 1g). The multiple comparison of marginal hook sickles as presented in Fig. 5, suggests that the large heel and the comparatively smaller, 

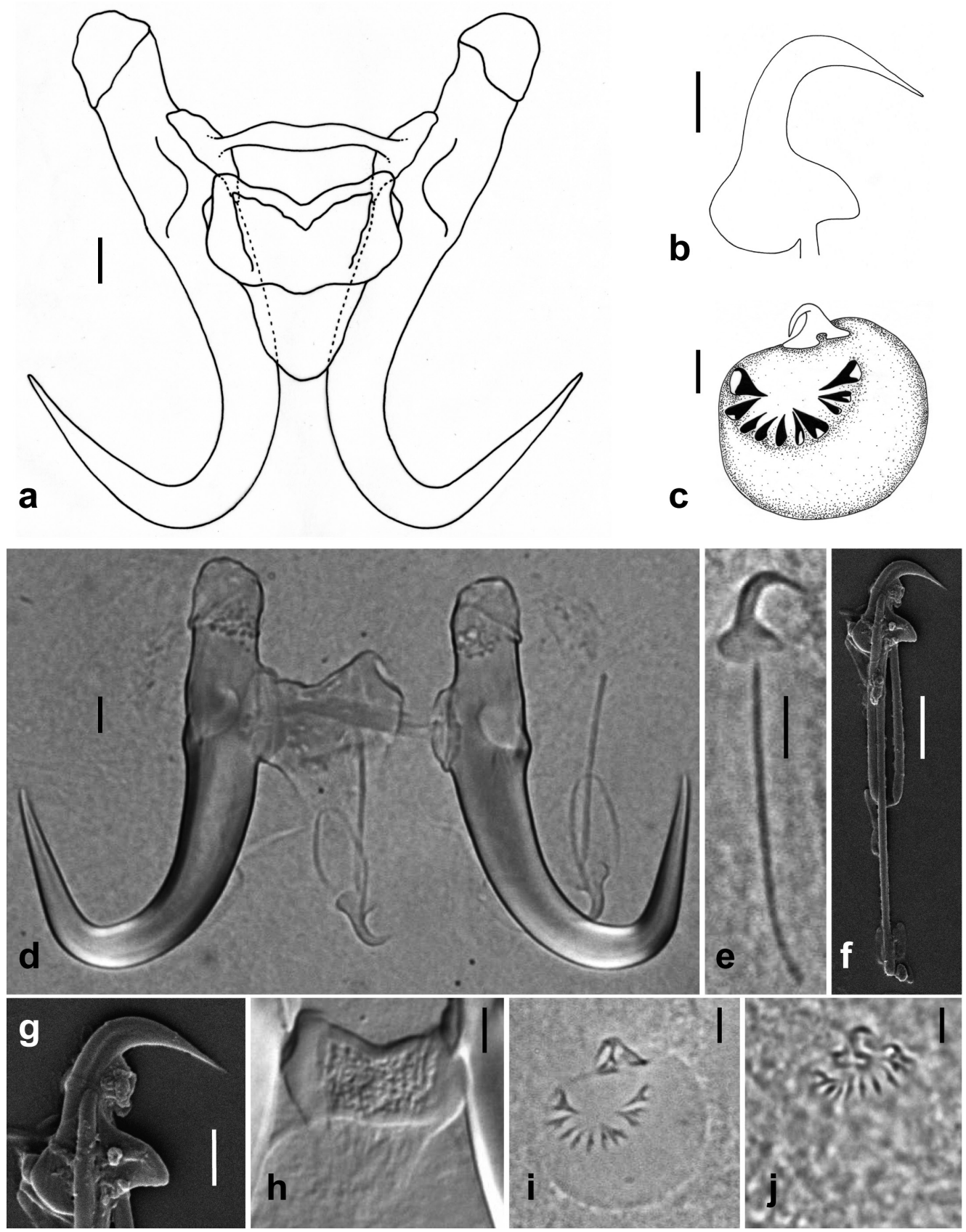

Fig. 1. Gyrodactylus corleonis sp. n. from Syngnathus typhle L. Drawings and light micrographs of the haptoral hard parts and male copulatory organ (MCO). a, $\mathbf{d}$ - central hook complex; b - marginal hook sickle; $\mathbf{c}, \mathbf{i}$ - MCO showing the normal arrangement of a single principal spine and 10-13 small spines in a single row; $\mathbf{e}$ - marginal hook; $\mathbf{f}, \mathbf{g}$ - scanning electron micrographs of the marginal hook released by proteolytic digestion; $\mathbf{h}$ - ventral bar; $\mathbf{j}-\mathrm{MCO}$ observed on one specimen showing the presence of a second, smaller upwardly curving spine, which arises from the end of the row of small spines that face the principal spine. Scale bars: a, c-f, $\mathrm{h}-\mathrm{j}=5 \mu \mathrm{m} ; \mathrm{b}, \mathrm{g}=2 \mu \mathrm{m}$.

raised toe permits this species to be separated from all the other species of Gyrodactylus parasitising syngnathid hosts.

The total length of the hamulus (HTL) can be used to clearly separate all the specimens of $G$. corleonis $(56.0$ \pm 1.2 ) considered in this study from the other specimens $(<50)$; this is shown in the PCA plot (Fig. 6).
Fig. $1 \mathrm{j}$ shows the apparent presence of a raised terminal MCO spine that curves upwards to face the principal spine on one of the five MCO-bearing specimens that were examined; this feature is discussed further for G. neretum where multiple specimens were found to possess this feature. 
Paladini et al.: Gyrodactylids from pipefish

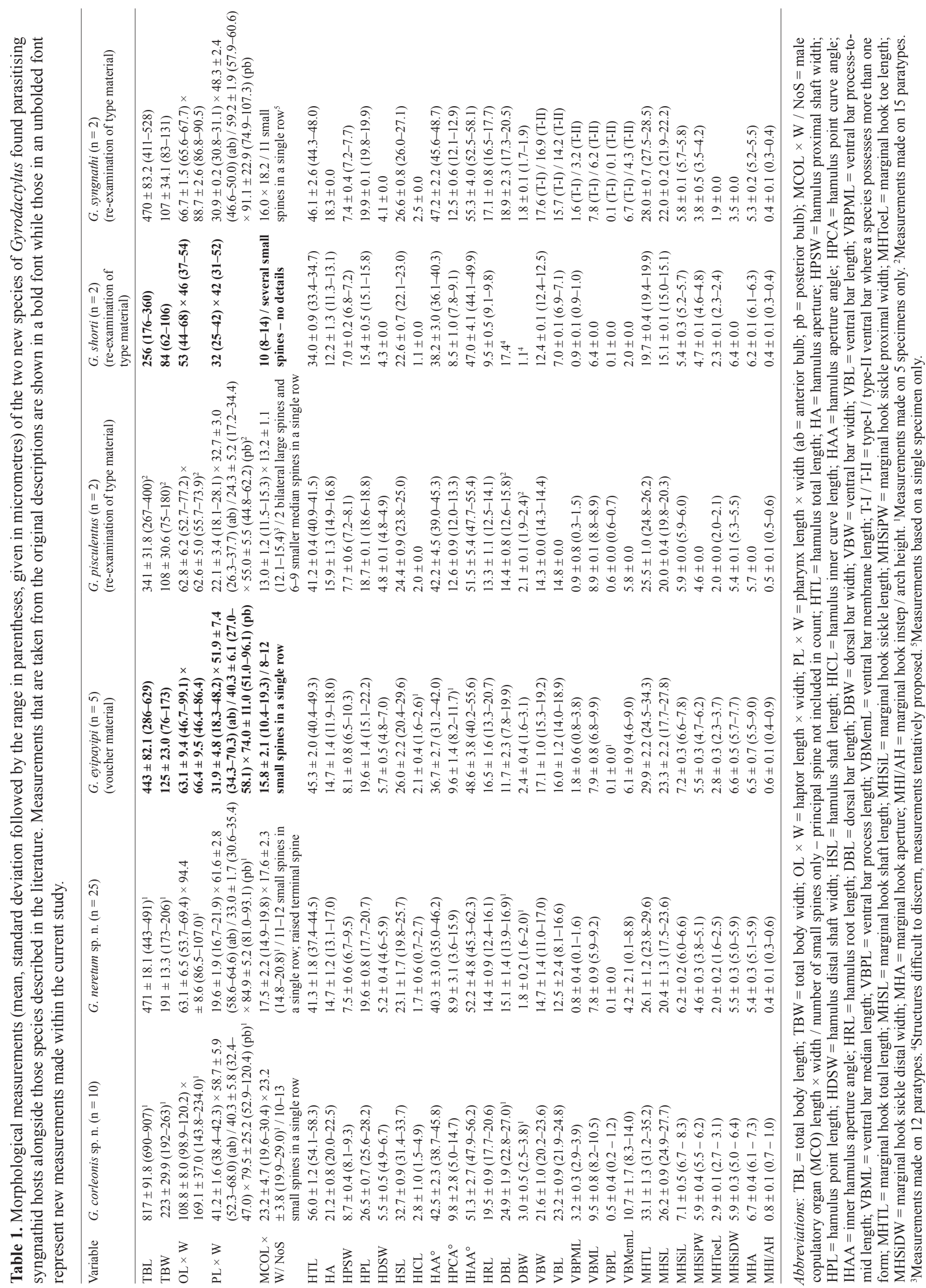



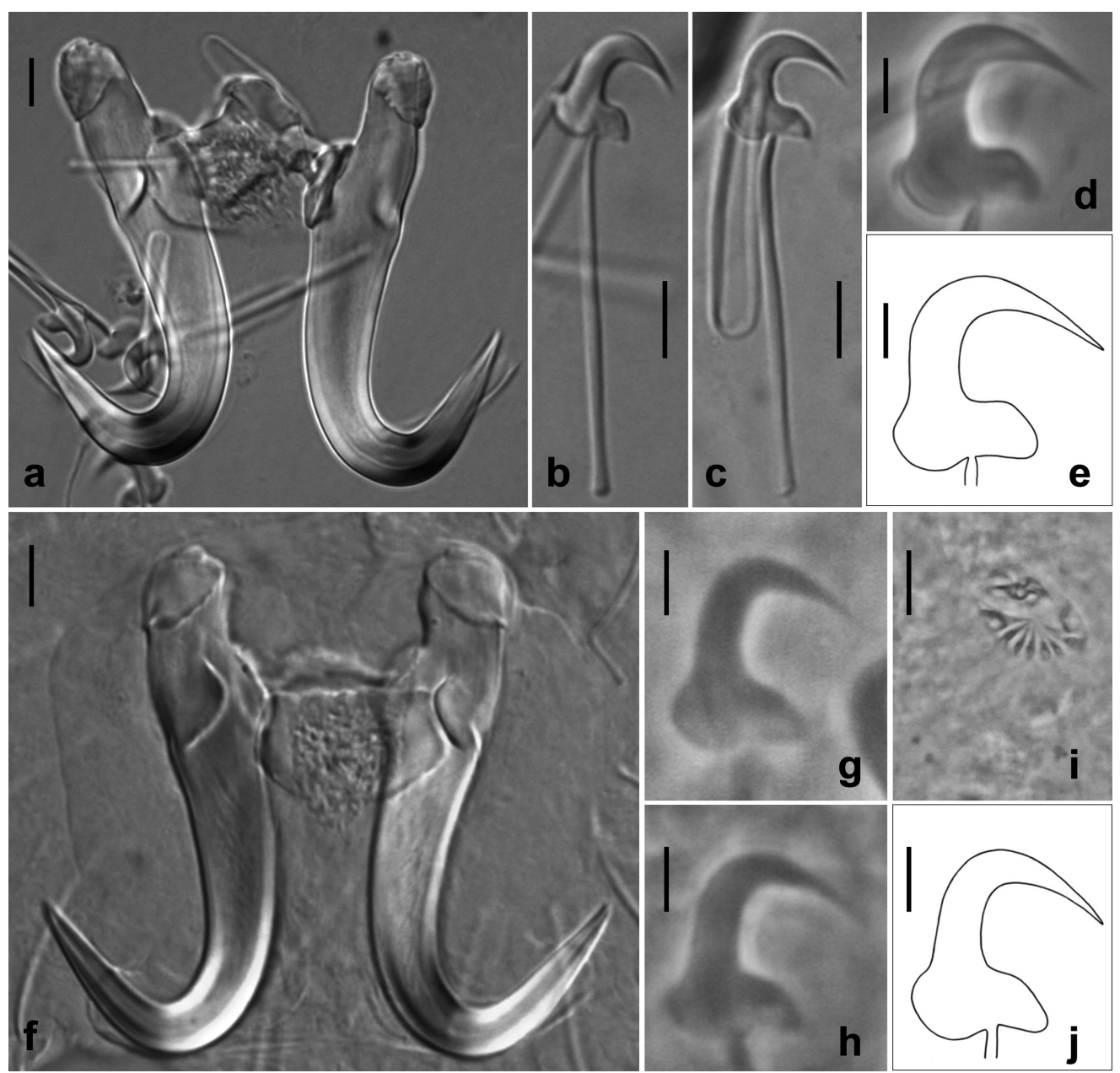

Fig. 2. a-e. Gyrodactylus eyipayipi Vaughan, Christison, Hansen et Shinn, 2010 from Syngnathus acus L. Light micrographs of the haptoral hard parts from the newly acquired material. a - central hook complex; b, c - marginal hooks; $\mathbf{d}$ - marginal hook sickle; e - drawing of the marginal hook sickle. f-j. Gyrodactylus pisculentus Williams, Kritsky, Dunnigan, Lash et Klein, 2008 from Syngnathus fuscus Storer. Light micrographs of the haptoral hard parts and MCO from the newly acquired material. $\mathbf{f}-$ central hook complex; $\mathbf{g}, \mathbf{h}$ - marginal hook sickles; $\mathbf{i}-\mathrm{MCO} ; \mathbf{j}$-drawing of the marginal hook sickle. Scale bars: a-c, f, i $=5 \mu \mathrm{m} ; \mathrm{d}, \mathrm{e}, \mathrm{g}, \mathrm{h}, \mathrm{j}=2 \mu \mathrm{m}$.

Gyrodactylus eyipayipi Vaughan, Christison, Hansen et Shinn, 2010

Fig. 2a-e, Table 1

Morphological description. Body elongate, 443 (286-629) long, 125 (76-173) wide. Anterior pharyngeal bulb 31.9 (18.3-48.2) long, 51.9 (34.3-70.3) wide; posterior pharyngeal bulb 40.3 (27.0-58.1) long, 74.0 (51.0-96.1) wide. Intestinal crura extend to the posterior end of the uterus. Haptor spherical, 63.1 (46.7-99.1) long $\times 66.4$ (46.4-86.4) wide. Male copulatory organ (MCO) spherical, 15.8 (10.4-19.3) in diameter, armed with one principal spine and a single row of 2 bilateral large spines and 6-10 smaller median spines. MCO position variable, usually posterior to the posterior pharyngeal bulb. Hamuli total length 45.3 (40.4-49.3); shaft length 26.0 (20.4-29.6); point $19.6(15.1-22.2)$ long, arises at angle of $48.6^{\circ}\left(40.2-55.6^{\circ}\right)$ (internal measurement) to the shaft of hamulus; root 16.5 (13.3-20.7) long. Dorsal bar simple, 11.7 (7.8-19.9) long, 2.4 (1.6-3.1) wide. Ventral bar square in approximate dimensions, $16.0(14.0-18.9)$ long,
17.1 (15.3-19.2) wide; ventral bar processes small, 0.1 long; ventral bar membrane short, approximately triangular with an irregular rounded terminal edge, 6.1 (4.6-9.0) long. Total length of marginal hooks 29.9 (24.5-34.3); shaft 23.3 (17.7-27.8) long; sickle proper 7.2 (6.6-7.8) long. Shaft and point regions of sickle curve smoothly. Sickle distal width 6.6 (5.7-7.7); proximal width 5.5 (4.76.2). Aperture of marginal sickle 6.5 (5.5-9.0) long, the inner curve of sickle describing a smooth curve. Toe 2.8 (2.3-3.7) long; heel rounded.

Host: Greater pipefish Syngnathus acus L. (Syngnathidae, Syngnathiformes).

L o c a 1 i ty: False Bay; Two Oceans Aquarium, Victoria \& Alfred Waterfront, Cape Town, South Africa.

Site of infection: Gills, entire body and lining of male brood pouch.

Voucher material examined: Five unmounted, ethanol-fixed specimens from the Department of Environmental Affairs and Tourism, Marine and Coastal Management, Roggebaai, South Africa. 
Molecular sequence data: Two sequences covering the internal transcribed spacer 1 and 2 and 5.8S are deposited in GenBank under Acc. Nos. FJ040183 and FJ040184.

Comments. Measurements of the five proteolytic digested specimens were compared to those presented in Vaughan et al. (2010) and found to fall within the measurement range for each variable. Three additional structures not presented in table 2 of Vaughan et al. (2010), i.e. the hamulus inner curve length, the hamulus point curve angle, and the ventral bar process length, are presented for the first time in the current study (Table 1). Photographs and drawings of the haptoral hooks of the newly acquired material were compared with those shown in Vaughan et al. (2010) and are presented in Fig. 2a-e. As there was good agreement between the measurements of the five specimens made in the current study with those made by Vaughan et al. (2010), the morphometric data from 48 specimens ( 5 from this study; the raw data for the 43 specimens measured and kindly provided by D. Vaughan) were included in the PCA.

The multiple comparison of marginal hook sickles as presented in Fig. 5 and the PCA plot (Fig. 6) confirm that $G$. eyipayipi can be separated from the other species of Gyrodactylus parasitising syngnathid hosts on the distal width of the marginal hook sickle (MHSiDW) (Table 1).

\section{Gyrodactylus neretum sp. n.}

Fig. 3, Table 1

Morphological description. Body elongate, 471 (443-491) long, 191 (174-206) wide. Haptor ovate, 63.1 (53.7-69.4) long $\times 94.4$ (86.5-107.0) wide. Anterior pharyngeal bulb 19.6 (16.7-21.9) long, 61.6 (58.6-64.6) wide; posterior bulb 33.0 (30.6-35.4) long, 84.9 (81.093.1 ) wide. Six to seven pharyngeal processes seen $12.7-$ 14.2 long. Intestinal crura terminate in line with posterior edge of uterus. MCO spherical, 17.5 (14.9-19.8) long $\times$ 17.6 (14.8-20.8) wide, position variable, usually medial, posterior to pharynx, armed with one principal spine and 11-12 small spines in a single row, two outer spines larger than the inner 10. Three of the six specimens with a MCO appear to bear a second small raised terminal spine. Hamuli robust, total length 41.3 (37.4-44.5); hamulus shaft 23.1 (19.8-25.7) long; hamulus point 19.6 (17.7-20.7) long, arising at a $52.2^{\circ}\left(45.3-62.3^{\circ}\right)$ (internal measurement) to the shaft of hamulus. Hamulus root short, 14.4 (12.4-16.1) long. Dorsal bar simple, 15.1 (13.9-16.9) long, 1.8 (1.6-2.0) wide. Ventral bar robust, 12.5 (8.116.6) long, 14.7 (11.0-17.0) wide; small ventral bar processes positioned on the anterior edge of the extremities of the median portion of the ventral bar, 0.1 long. Ventral bar membrane short, triangular, $4.2(0.1-8.8)$ long. Total length of marginal hooks 26.1 (23.8-29.6); marginal hook shaft 20.4 (17.5-23.6) long; marginal hook sickle proper 6.2 (6.0-6.6) long with a broad sickle shaft, that curves smoothly into a long point that terminates at a point beyond the limit of toe. Sickle distal width 5.5 (5.0-5.9);
Table 2. Percentage of the variance explained and the component loadings for the first two principal components explained by the 22 measurements made on the haptoral attachment hooks of Gyrodactylus corleonis sp. n. from Syngnathus typhle L., Gyrodactylus neretum sp. n. from Syngnathus scovelli (Evermann et Kendall), Gyrodactylus eyipayipi Vaughan, Christison, Hansen et Shinn, 2010 from Syngnathus acus L., Gyrodactylus pisculentus Williams, Kritsky, Dunnigan, Lash et Klein, 2008 from Syngnathus fuscus Storer, Gyrodactylus shorti Holliman, 1963 from S. scovelli and Gyrodactylus syngnathi Appleby, 1996 from Syngnathus rostellatus Nilsson. Variables that make a notable contribution to the separation of specimens within the principal components analysis are highlighted in a bold font (i.e. above \pm 0.7 )

\begin{tabular}{lcc}
\hline & Factor (1) & Factor (2) \\
\hline Total variance explained (\%) & 47.09 & 16.67 \\
Cumulative variance (\%) & 47.09 & 63.76 \\
Hamulus total length & $\mathbf{- 0 . 9 1 3}$ & 0.224 \\
Hamulus aperture & 0.006 & $\mathbf{0 . 7 9 8}$ \\
Hamulus proximal shaft width & -0.561 & 0.040 \\
Hamulus point length & $\mathbf{- 0 . 7 0 9}$ & 0.505 \\
Hamulus distal shaft width & -0.450 & -0.441 \\
Hamulus shaft length & $\mathbf{- 0 . 8 1 8}$ & 0.242 \\
Hamulus aperture angle & 0.005 & $\mathbf{0 . 7 9 8}$ \\
Hamulus root length & $\mathbf{- 0 . 8 0 8}$ & 0.124 \\
Ventral bar width & $\mathbf{- 0 . 8 8 6}$ & 0.104 \\
Ventral bar length & $\mathbf{- 0 . 8 9 7}$ & 0.123 \\
Ventral bar process-to-mid length & -0.631 & -0.098 \\
Ventral bar median length & -0.501 & 0.283 \\
Ventral bar process length & -0.485 & 0.563 \\
Ventral bar membrane length & -0.699 & 0.078 \\
Marginal hook total length & $\mathbf{- 0 . 8 4 2}$ & -0.144 \\
Marginal hook shaft length & $\mathbf{- 0 . 7 9 5}$ & -0.099 \\
Marginal hook sickle length & $\mathbf{- 0 . 7 0 9}$ & -0.535 \\
Marginal hook sickle proximal width & $\mathbf{- 0 . 7 7 6}$ & -0.409 \\
Marginal hook toe length & -0.694 & -0.447 \\
Marginal hook sickle distal width & -0.230 & $-\mathbf{0 . 8 3 0}$ \\
Marginal hook aperture & -0.605 & -0.428 \\
Marginal hook instep / arch height & -0.686 & -0.090 \\
\hline
\end{tabular}

proximal width $4.6(3.8-5.1)$. Toe short, triangular, 2.0 (1.6-2.5) long; heel rounded.

Type host: Gulf pipefish Syngnathus scovelli (Evermann et Kendall) (Syngnathidae, Syngnathiformes).

Collection site: Large public aquarium in the EmiliaRomagna region of Italy. Aquarium records suggest, though not confirmed, that the single specimen of $S$. scovelli was collected from the Atlantic coast of the United States of America, near Baltimore, Maryland.

Site of infection: Gills, skin and fins.

Type material: Twenty-five specimens were studied for light microscopy. Holotype (BMNH Reg. No. 2008.12.15.5) and one paratype (BMNH Reg. No. 2008.12.15.6) are deposited in the Parasitic Worm Collection at The Natural History Museum, London. One paratype (M-477/1) is deposited in the gyrodactylid collection held at the Institute of Parasitology, Biology Centre of the Academy of Sciences of the Czech Republic, České Budějovice. Additionally, 22 paratypes (AHC 29836-29857) are deposited in the Australian 

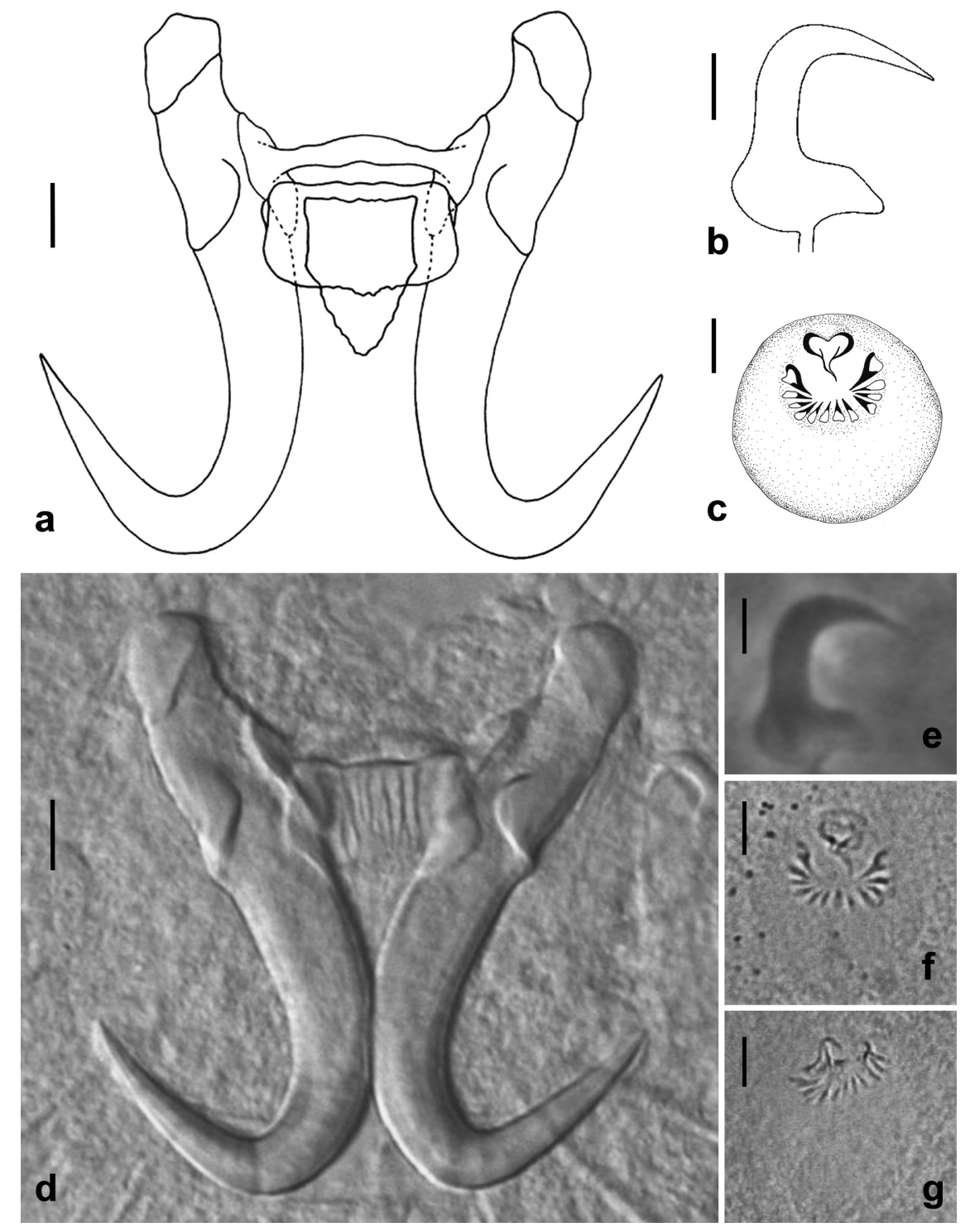

Fig. 3. Gyrodactylus neretum sp. n. from Syngnathus scovelli (Evermann et Kendall). Drawings and light micrographs of the haptoral hard parts and male copulatory organ (MCO). a, $\mathbf{d}$ - central hook complex; b, e - marginal hook sickle; $\mathbf{c}, \mathbf{f}-\mathrm{MCO}$ (normal Gyrodactylus-type) with one principal spine and 11-12 small spines in a single row; $\mathbf{g}$ - MCO showing the presence of a second upwardly curving spine which appears to rise from the small row of spines to face the principal spine. Scale bars: a, c, d, f, g= $5 \mu \mathrm{m}$; $\mathrm{b}, \mathrm{e}=2 \mu \mathrm{m}$.

Helminthological Collection (AHC) of The South Australian Museum (SAMA), North Terrace, Adelaide.

Etymology: Named after the Latin name of the old city Nardó (southern Italy) where much of the work involved in describing this species was undertaken.

Molecular sequence data: Sequences of 1227 bp encoding the 18S (21 bp), ITS1 (595 bp), 5.8S (158 bp), ITS2 (398 bp) and 28S (55 bp) are deposited in GenBank under Acc. No. FJ183748.

Molecular characterisation. In contrast to G. corleonis, the ITS1 of G. neretum was classified as a "long fragment" (595 bp) and the $5.8 \mathrm{~S}$ sequence was $158 \mathrm{bp}$, once more differing from the majority of Gyrodactylus species that have a 5.8S gene of $157 \mathrm{bp}$ (Ziętara and Lumme 2004). BLAST searches of G. neretum ITS1 revealed no strong similarities with any other Gyrodactylus species, the closest related species was $G$. cf. micropsi with $84 \%$ identity but only $61 \%$ coverage. The $5.8 \mathrm{~S}$ gene of G. neretum showed $98 \%$ identity with $G$. corleonis and G. eyipayipi, $96 \%$ identity with $G$. anguillae, $G$. cf. $m i-$ cropsi, G. kobayashii, G. longidactylus, G. rugiensis and G. sprostonae (coverage of $100 \%$ ). The lowest pairwise distance values were found among comparisons between G. corleonis, G. eyipayipi and G. sprostonae (all p-distance $=0.019)$. The BLAST searches of ITS2 showed $82 \%$ identity with $G$. anguillae, $80 \%$ with $G$. cf. micropsi, 
G. longidactylus, G. rugiensis and G. rugiensoides (average coverage of $90 \%$ ). The lowest pairwise distance value was found when comparing with $G$. corleonis ( $p=0.033$ ). Neighbour-Joining trees generated using the whole 5.8S sequence and $215 \mathrm{bp}$ of ITS2 clustered $G$. neretum with G. corleonis (Fig. 7). When analysing the $5.8 \mathrm{~S}$ gene sequences separately, G. sprostonae also clustered within this group (data not shown).

Comments. One of the most notable features of this species is the apparent presence in the MCO of a second raised spine. In three out of the six MCO-bearing specimens that were prepared for light microscopy (Fig. 3c, g), one of the larger peripheral spines from the row of small spines curves upwards to face the main principal spine. It is unlikely that this represents distortion and damage to the MCO as this was seen on several specimens and represents the first time that the MCO spines have been observed in this configuration for any species of the genus. This feature was also observed on one of the five MCObearing specimens of $G$. corleonis.

Of the two new species of Gyrodactylus found in this study, G. corleonis is the larger species (Fig. 1, Table 1) and can be readily differentiated from $G$. neretum by differences in the shape and/or size of all three major haptoral hard structures (hamulus, ventral bar and marginal hook). The hamuli of $G$. neretum are smaller than those of $G$. corleonis (total length 41.3 vs. 56.0; aperture 14.7 vs. 21.2) and, proportionately, more robust. The ventral bars also differ in overall proportions (VB total width 21.6 G. corleonis vs. 14.7 G. neretum; VB total length 23.2 G. corleonis vs. 12.5 G. neretum; VB process length $0.5 \mathrm{G}$. corleonis vs. $0.1 \mathrm{G}$. neretum) and the shape of the membrane, which is large and lingulate in G. corleonis and small and triangular in G. neretum. The marginal hooks also differ in the dimensions of almost all the measured parameters (total length, shaft length, sickle length, toe length, aperture and instep height) (Table 1). If the effects of size are removed and the shape of the similarsized marginal hooks is compared, then it can be seen that they differ in the shape of the sickle base, which is deeper in $G$. corleonis, notably the heel region, which is more rounded.

Gyrodactylus neretum and G. shorti both infect S. scovelli and the marginal hooks of both species are morphologically very similar when the effect of size is removed (Fig. 5m). Only the attachment point of the marginal hook shaft with the sickle appears to differ, with $G$. neretum attaching closer to the heel, giving it a proportionately longer toe. The length of the marginal hooks of G. neretum is longer (Table 1) and the differences in the shape of the hamuli and the ventral bar, however, are marked (Figs. 3, 4a, b).

Despite the morphological similarities between G. neretum and G. shorti, these two species occupy different niches on the same host, the former principally on the gills with individuals also recovered from the fins and skin, while the latter is recorded from the brood pouch. Although G. shorti and G. neretum originate from geographically distinct waterbodies, Tampa Bay on the Gulf of Mexico, USA and the Atlantic coast near Baltimore, respectively, additional specimens and molecular sequences for $G$. shorti are now required to investigate these species further.

Gyrodactylus pisculentus Williams, Kritsky, Dunnigan, Lash et Klein, $2008 \quad$ Fig. $2 \mathrm{f}-\mathrm{j}$, Table 1

Morphological description. Formalin-fixed specimens with body fusiform, robust, 341 (267-400) long, 108 (75-180) wide at level of uterus. Haptor spherical, $62.8(52.7-77.2)$ long $\times 62.6(55.7-73.9)$ wide. Pharynx anterior bulb $22.1(18.1-28.1)$ long $\times 32.7(26.3-37.7)$ wide, posterior bulb 24.3 (17.2-34.4) long $\times 55.0$ (44.8$62.2)$ wide. Intestinal crura extend to the posterior end of the uterus. MCO spherical, 13.0 (11.5-15.3) long $\times 13.2$ (12.1-15.4) wide, armed with one principal spine and a single row consisting of 2 bilateral large spines and 6-9 smaller median spines. MCO position variable mediolateral, overlies posterior edge of posterior pharyngeal bulb. Hamuli total length 41.2 (40.9-41.5); shaft length 24.4 (23.8-25.0); point 18.7 (18.6-18.8) long, arises at angle of $51.5^{\circ}\left(47.7-55.4^{\circ}\right)$ (internal measurement) to the shaft of hamulus; root 13.3 (12.5-14.1) long. Dorsal bar simple, 14.4 (12.6-15.8) long, 2.1 (1.9-2.4) wide. Ventral bar 14.8 (14.8-14.8) long, 14.3 (14.3-14.4) wide; ventral bar processes small, $0.6(0.6-0.7)$ long; ventral bar membrane short, rounded, 5.8 (5.8-5.8) long. Total length of marginal hooks 25.5 (24.8-26.2); shaft 20.0 (19.8-20.3) long; sickle proper 5.9 (5.9-6.0) long. Shaft and point regions of sickle curve smoothly and taper to a fine point far beyond the toe. Sickle distal width 5.4 (5.3-5.5); proximal width 4.6 (4.6-4.6). Aperture of marginal sickle, 5.7 (5.7-5.7) long. Toe triangular, 2.0 (2.0-2.1) long; heel approximately rounded.

H o s t: Northern pipefish Syngnathus fuscus Storer (Syngnathidae, Syngnathiformes).

L o c a lity: Environs of Wood Hole, Massachusetts $\left(41^{\circ} 31^{\prime} \mathrm{N}\right.$, $\left.70^{\circ} 31^{\prime} \mathrm{W}\right)$.

Site of infection: Head, body and fins.

Type and voucher material examined: Five paratypes from The Natural History Museum, London, UK (BNHM 2008.4.8.1-10) and 10 paratypes from the United States National Parasite Collection, Beltsville, Maryland, USA (USNPC Helm. Coll. No. 100699). In addition, eight formalin-fixed specimens from $S$. fuscus were kindly donated by Prof. D. Kritsky (Idaho State University, Pocatello, USA).

Comments. Only 2 of the 15 paratypes that were borrowed from the two museums were unstained and used for the comprehensive examination of the haptoral hard parts. Selected measurements were made on the remaining specimens which were not completely flat and were stained with Gomori's trichrome which obscured a clear 
view of certain haptoral structures. A re-examination of this species was possible following the loan of additional formalin fixed material of G. pisculentus from S. fuscus, eight of which were subjected to proteolytic digestion. The morphology of the haptoral hard parts of both sets of material was found to be in good agreement. Light micrographs and drawings of the marginal hook sickle from the paratypes are presented in Fig. $2 \mathrm{~g}, \mathrm{~h}, \mathrm{j}$.

\section{Gyrodactylus shorti Holliman, 1963}

Fig. 4a, b, Table 1

Morphological description. Formalin-fixed specimens. The dimensions of the entire worms were not measured in the current study but are taken from Holliman's original account and given as 256 (176-360) long, 84 (62$106)$ wide. Haptor spherical, 53 (44-68) long $\times 46$ (3754) wide. Pharynx 32 (25-42) long $\times 42(31-52)$ wide. MCO diameter 10 (8-14) bearing several small spines (no details). No MCO was visible on the holotype/paratypes but the account of Holliman (1963) suggest that 10 (8-14) small spines are present. The following measurements of haptoral hard parts are presented after re-examination of type material, however, none of the specimens were flat and measurements are tentatively presented. Hamulus total length 34.0 (33.4-34.7), hamulus shaft length 22.6 (22.1-23.0), hamulus point 15.4 (15.1-15.8) long arising at $47.0^{\circ}\left(44.1-49.9^{\circ}\right)$ (internal measurement) angle to hamulus shaft. Hamulus roots appear to curve inwards, 9.5 (9.1-9.8) long. Dorsal bar said to be absent in the original description but on re-examination is present, simple 17.4 long, 1.1 wide. Ventral bar 7.0 (6.9-7.1) long, 12.4 (12.412.5 ) wide; ventral bar processes almost non-existent 0.1 long; median portion of ventral bar marked by hump on anterior edge; ventral bar membrane short, 2.0 long. Total length of marginal hooks 19.7 (19.4-19.9); marginal hook shaft 15.1 (15.0-15.1) long; marginal hook sickle proper 5.4 (5.2-5.7) long. Shaft proportionately broad curves smoothly and tapers to fine point beyond limit of toe. Sickle distal width 6.4; proximal width 4.7 (4.6-4.8). Toe approximately triangular in shape, 2.3 (2.3-2.4) long.

H o s t: Gulf pipefish Syngnathus scovelli (Evermann et Kendall) (Syngnathidae, Syngnathiformes).

Locality: Tampa Bay, Florida $\left(27^{\circ} 43^{\prime} 15.51^{\prime \prime} \mathrm{N}\right.$, $\left.82^{\circ} 34^{\prime} 43.72^{\prime \prime} \mathrm{W}\right)$.

Site of infection: Brood pouch of a male fish.

Type material examined: Holotype and two paratypes (USNPC Helm. Coll. No. 59597).

Comments. Holliman's (1963) original description was based on the removal of material from a formalinfixed host in which he made a comment regarding the quality of the slide-mounted preparations. Given the rigid nature of the material and the resultant poor preparation of the holotype and the two paratypes (deposited in the USDA U.S. National Parasite Collection), several impor- tant haptoral features were overlooked and this species is tentatively redescribed here. The drawings in Holliman's (1963) original description are incomplete and do not accurately reflect the morphological form of the haptoral hard parts. Specifically, the drawing of the ventral bar is incomplete and has been drawn without a membrane and the characteristic medial hump on the anterior edge of the median portion. Holliman (1963) commented on the unique nature of this Gyrodactylus species in that it lacked a dorsal bar, however, on re-examination of type material, a simple dorsal bar was observed as being present. The precise shapes of the hamuli were difficult to discern, but have been reconstructed from a series of images taken through the specimens and reconstructed using image analysis (see Fig. 4a). From the images, it appears as though the hamuli possess short roots, $9.5 \mu \mathrm{m}$ long, that turn inwards. Details pertaining to the marginal hook were also lacking from the original description and only their total length was provided. The marginal sickles, however, are morphologically very similar to G. neretum and this is discussed in the comments section of the latter species.

\section{Gyrodactylus syngnathi Appleby, 1996}

Fig. $4 c-j$, Table 1

Morphological description. Body elongate, 470 (411-528) long, 107 (83-131) wide. Anterior pharyngeal bulb 30.9 (30.8-31.1) long $\times 48.3(46.6-50.0)$ wide; posterior pharyngeal bulb $59.2(57.9-60.6)$ long $\times 91.1(74.9-$ $107.3)$ wide. Dimensions of the pharyngeal processes difficult to determine. Haptor ovate, 66.7 (65.6-67.7) long $\times 88.7(86.8-90.5)$ wide. Intestinal crura extend beyond testes. MCO spherical, 16.0 long $\times 18.2$ wide, armed with one principal spine and $8-11$ small spines in single row. MCO positioned lateral and posterior to posterior pharyngeal bulb. Total length of hamuli 46.1 (44.3-48.0); hamulus shaft length 26.6 (26.0-27.1); hamulus point $19.9(19.8-19.9)$ long, set at $55.3^{\circ}\left(52.5-58.1^{\circ}\right)$ (internal measurement) angle to shaft of hamulus; hamulus roots straight, 17.1 (16.5-17.7) long. Dorsal bar simple, 18.9 (17.3-20.5) long, 1.8 (1.7-1.9) wide. Two forms of ventral bar were seen in paratypes of $G$. syngnathi, which were not commented upon in original description. Ventral bar type-I broad, rectangular-shaped median portion with triangular membrane. Ventral bar total length 15.7; total width 17.6; ventral bar processes virtually non-existent, 0.1 long; median bar broad, rectangular, 7.8 long; ventral bar membrane triangular, 6.7 long. Ventral bar typeII labrys-shaped median portion with small triangular membrane. Ventral bar total length 14.2; total width 16.9; process-to-mid length 3.2 ; median length 6.2 ; ventral bar processes virtually non-existent, 0.1 long; membrane triangular, 4.3 long. Total length of marginal hooks 28.0 (27.5-28.5); marginal hook shaft 22.0 (21.9-22.2) long; marginal hook sickle proper 5.8 (5.7-5.8) long; shaft and 

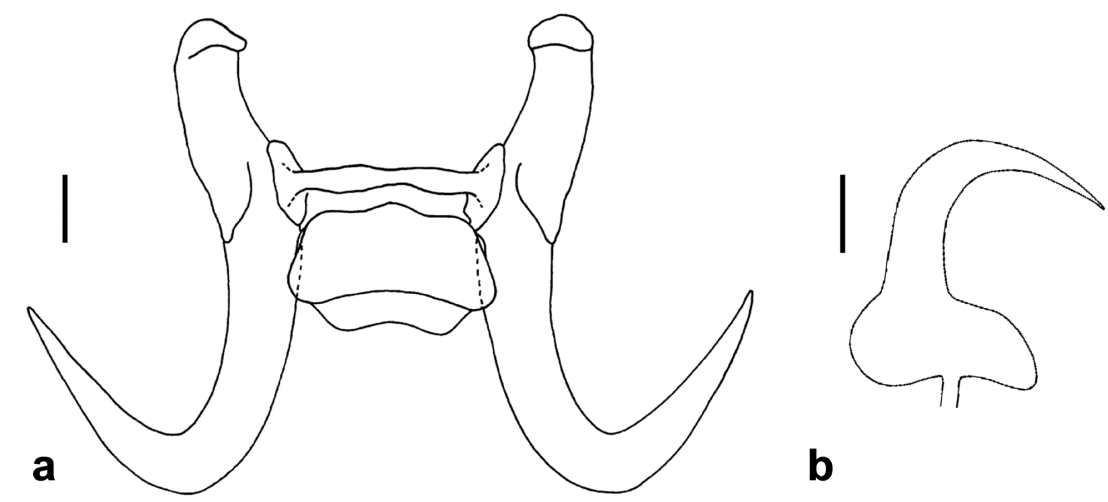

b
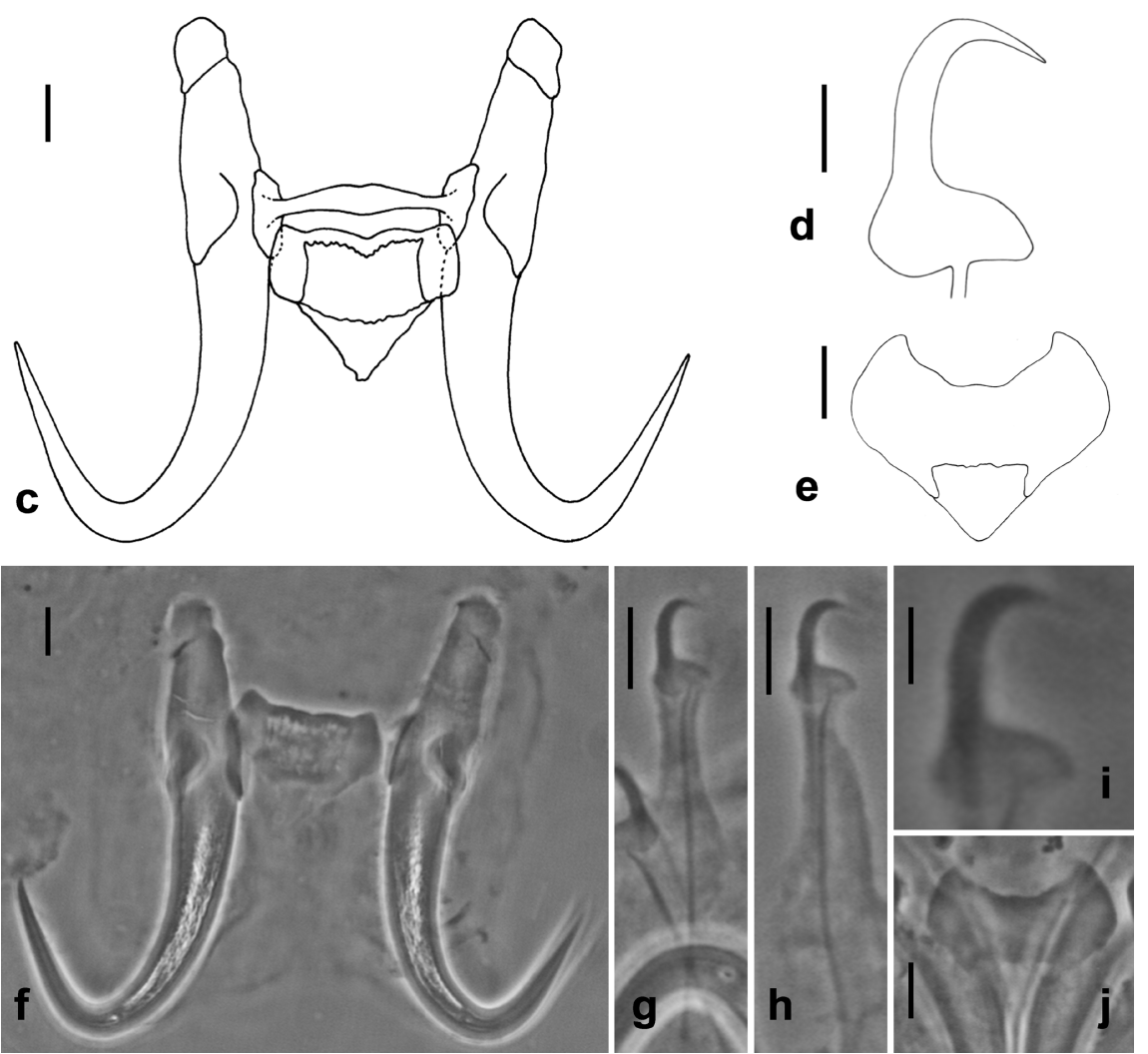

Fig. 4. a, b. Gyrodactylus shorti Holliman, 1963 from Syngnathus scovelli (Evermann et Kendall). Drawings of the haptoral hard parts. a - central hook complex (re-examination); b - marginal hook sickle (re-examination). c-j. Gyrodactylus syngnathi Appleby, 1996 from Syngnathus rostellatus Nilsson. Drawings and light micrographs of the haptoral hard parts. c, f - central hook complex with ventral bar type-I (re-examination); d, i - marginal hook sickle (re-examination); e, $\mathbf{j}$ - ventral bar type-II (re-examination); $\mathbf{g}, \mathbf{h}$ - marginal hooks. Scale bars: $\mathrm{a}, \mathrm{c}, \mathrm{e}-\mathrm{h}, \mathrm{j}=5 \mu \mathrm{m} ; \mathrm{b}, \mathrm{d}, \mathrm{i}=2 \mu \mathrm{m}$.

point regions slender; short point terminating in line with toe; distal width 3.5; proximal width 3.8 (3.5-4.2); toe triangular, 1.9 long; heel rhomboid in approximate shape.

Host: Syngnathus rostellatus Nilsson (Syngnathidae, Syngnathiformes).

L o c a l i ty: Hvervenbukta, Oslo, Norway $\left(59^{\circ} 50^{\prime} \mathrm{N}, 10^{\circ} 46^{\prime} \mathrm{E}\right)$.

Site of infection: Skin and fins.

Type material examined: Two paratypes BMNH Reg. No. 1995.9.7.2-4 (slides 5 and 8).
Comments. There is good agreement between the measurements made on the two paratypes acquired for the current study and the original measurements provided by Appleby (1996). However, the shape of the ventral bar of the two paratypes differs as revealed by slowly focusing through the specimens using a $\times 100$ objective with oil immersion. It is recommended that future studies investigate this and sequence representatives displaying each type to determine whether they represent a single species or not. 


\section{G. eyipayipi \\ G. pisculentus \\ G. shorti \\ G. syngnathi}

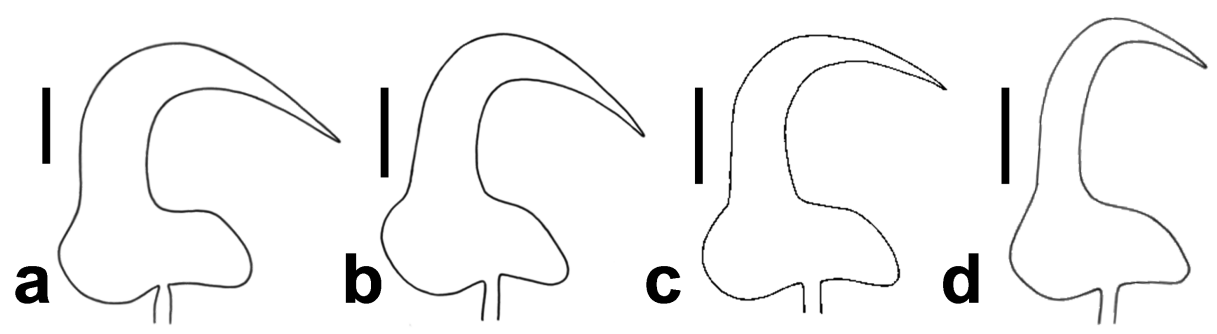

G. corleonis sp. $\mathrm{n}$.
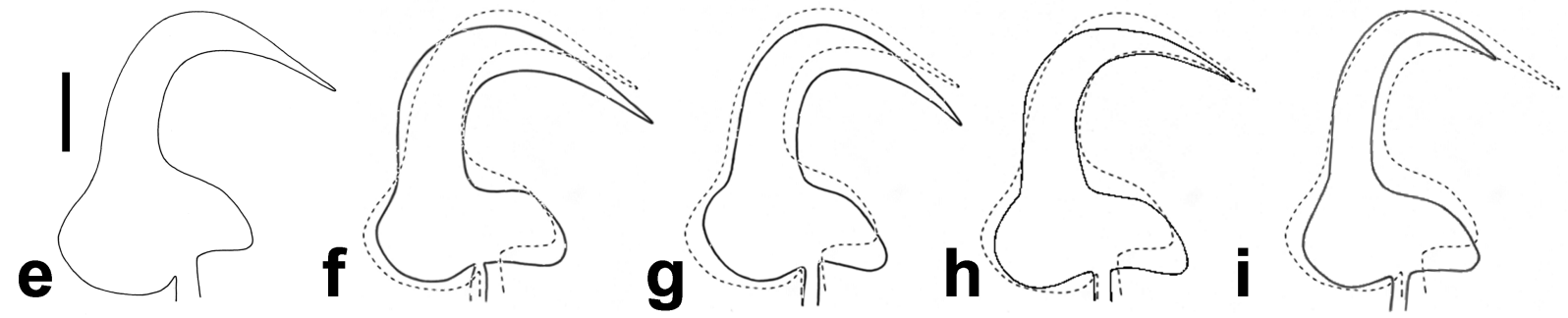

G. neretum sp. n.
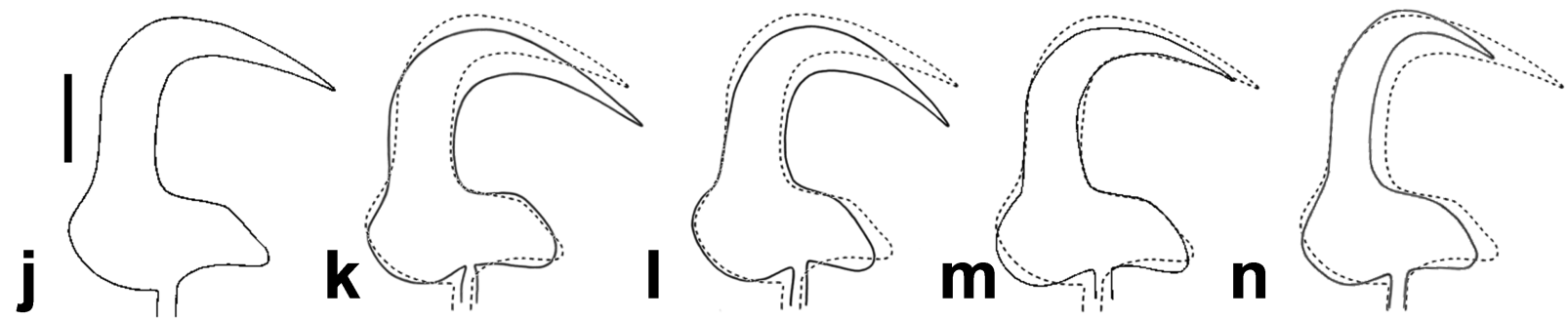

Fig. 5. A size invariant comparison of the marginal hook sickles of two new species of Gyrodactylus with the four species previously recorded infecting pipefish. a - Gyrodactylus eyipayipi Vaughan, Christison, Hansen et Shinn, 2010 (re-examination); b - Gyrodactylus pisculentus Williams, Kritsky, Dunnigan, Lash et Klein, 2008 (re-examination); c - Gyrodactylus shorti Holliman, 1963 (re-examination); d - Gyrodactylus syngnathi Appleby, 1996 (re-examination); e - Gyrodactylus corleonis sp. n.; f-i - overlay of G. corleonis (broken line) with G. eyipayipi (f), G. pisculentus (g), G. shorti (h), and G. syngnathi (i); j-Gyrodactylus neretum sp. n.; k-n - overlay of G. neretum (broken line) with G. eyipayipi (k), G. pisculentus (1), G. shorti (m), and G. syngnathi (n). Scale bars $=2 \mu \mathrm{m}$.

The morphology of the marginal hook sickle of G. syngnathi is quite unlike those of the other species and is readily discriminated. The marginal hook distal width is comparatively narrow (Table 1, Fig. 5) and is one of the main features pulling G. syngnathi out along Factor 2 in the PCA plot (Fig. 6).

\section{DISCUSSION}

Among the gyrodactylids considered here from pipefish, two constitute new species, Gyrodactylus corleonis and G. neretum, which can be separated on the basis of subtle differences in the morphology of their haptoral hard parts (Figs. 5, 6). Molecular sequence data are now required for G. pisculentus, G. shorti and G. syngnathi to confirm or disprove the current species identities based on morphology.

Of the six species considered here from pipefish, only the marginal hook sickles of G. syngnathi are markedly different. The marginal hook sickles of the remaining five species all possess gently curving sickle shaft regions that terminate in a point far beyond the line of the toe. The separation of these latter species, based on only the marginal hook sickle, is difficult and requires additional information taken from the other haptoral hard parts, i.e. the hamuli and the ventral bar, for confident identifications to be made. The sickle base region of the marginal hook sickles, however, is perhaps the most discriminating feature; the heel of G. corleonis is large and rounded and drops below the level of the toe; the heel of G. neretum 


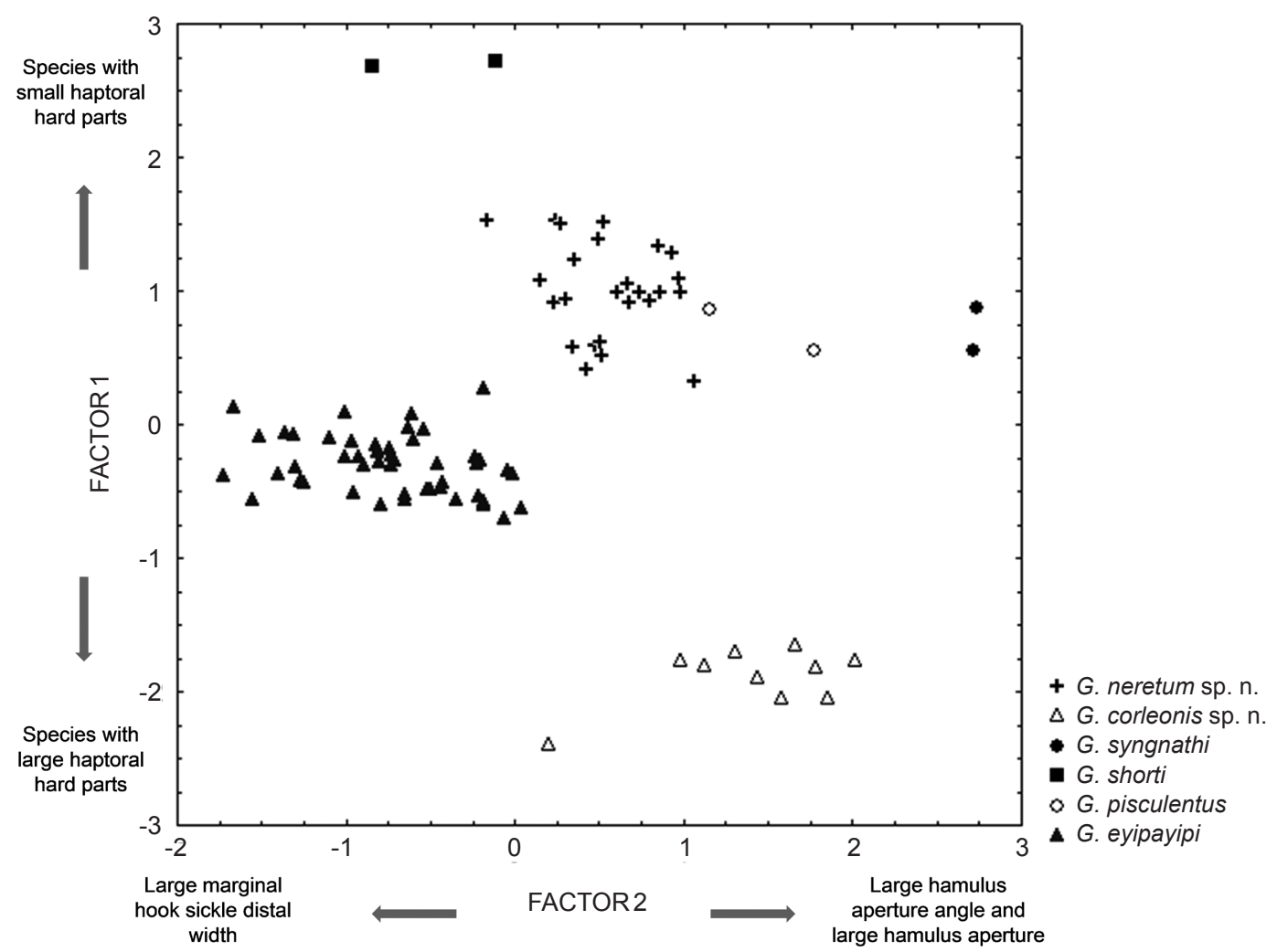

Fig. 6. Principal Components Analysis (PCA) plot of the 22 point-to-point measurements (log data) made on the two new species of Gyrodactylus collected from Syngnathus scovelli (Evermann et Kendall) (Gyrodactylus neretum sp. n.) and Syngnathus typhle L. (Gyrodactylus corleonis sp. n.) and compared with morphometric data made on specimens of Gyrodactylus eyipayipi Vaughan, Christison, Hansen et Shinn, 2010, Gyrodactylus pisculentus Williams, Kritsky, Dunnigan, Lash et Klein, 2008, Gyrodactylus shorti Holliman, 1963 and Gyrodactylus syngnathi Appleby, 1996 to look at their relative relationship to one another. Separation of the specimens is principally influenced by the hamulus total length (HTL) acting along Factor 1 and by the marginal hook sickle distal width (MHSiDW) acting along Factor 2.

is reduced and has an angular, proportionately long toe; the toe region of $G$. eyipayipi is large with a flat bridge; the heel of $G$. pisculentus is approximately rhomboid and has a deeper sickle base than that of G. eyipayipi; and, the heel of G. shorti is prominently rounded and has a marked

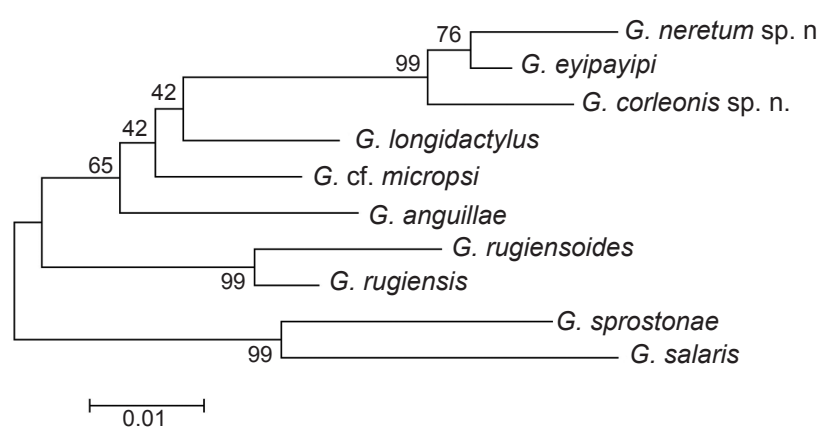

Fig. 7. Neighbour-Joining tree of the $371 \mathrm{bp}$ comprising the ITS2 region and the $5.8 \mathrm{~S}$ gene of ten Gyrodactylus species. angular connection with the shaft region of the sickle. As there were difficulties in determining the precise shape of the haptoral hooks in the formalin-fixed G. shorti specimens, its comparison with the other species of Gyrodactylus presented must be regarded tentative until further specimens can be secured.

Acknowledgements. The authors would like to thank Patricia Pilitt from the USDA U.S. National Parasite Collection for the loan of G. shorti and G. pisculentus type materials and Eileen Harris from the Parasitic Worms Division, The Natural History Museum, London for the loan of the G. pisculentus and G. syngnathi paratypes. We also gratefully acknowledge the Degree Course of Aquaculture and Ichthyopathology, Cesenatico (FC), Italy for financial assistance in supporting this research, Dr. Daniela Florio (University of Bologna, Italy) and Dr. Lara Fichtel for making moribund specimens of infected pipefish available for study. PJF and JC were supported by a European Community Framework Programme 6 Marie Curie Host Fellowship for Transfer of Knowledge (MTKD-CT-2005-030018). 
AppleBy C. 1996: Gyrodactylus syngnathi n. sp. (Monogenea: Gyrodactylidae) from the pipefish Syngnathus rostellatus Nilsson, 1855 (Syngnathiformes: Syngnathidae) from the Oslo Fjord, Norway. Syst. Parasitol. 33: 131-134.

Cable J., Harris P.D., Tinsley R.C., Lazarus C.M. 1999: Phylogenetic analysis of Gyrodactylus spp. (Platyhelminthes: Monogenea) using ribosomal DNA sequences. Can. J. Zool. 77: 1439-1449.

Cable J., van Oosterhout C., Barson N., Harris P.D. 2005: Gyrodactylus pictae n. sp. (Monogenea: Gyrodactylidae) from the Trinidadian swamp guppy Poecilia picta Regan, with a discussion on species of Gyrodactylus von Nordmann, 1832 and their poeciliid hosts. Syst. Parasitol. 60: 159-164.

Cunningham C.O. 1997: Species variation within the internal transcribed spacer (ITS) region of Gyrodactylus (Monogenea: Gyrodactylidae) ribosomal RNA genes. J. Parasitol. 83: 215219.

Harris P.D., Shinn A.P., Cable J., Bakke T.A. 2004: A complete host-species list for the genus Gyrodactylus (Monogenea, Gyrodactylidae). Syst. Parasitol. 59: 1-27.

Harris P.D., Shinn A.P., Cable J., Bakke T.A., Bron J.E. 2008: GyroDb: gyrodactylid monogeneans on the web. Trends Parasitol. 24: 109-111.

Holliman R.B. 1963: Gyrodactylus shorti, a new species of monogenetic trematode from the brood pouch of the southern pipefish, Syngnathus scovelli (Evermann and Kendall). Tulane Stud. Zool. 10: 83-86.

Jeanmougin F., Thompson J.D., Gouy M., Higgins D.G., Gibson T.J. 1998: Multiple sequence alignment with Clustal X. Trends Biochem. Sci. 23: 403-405.

Matějusová I., Gelnar M., McBeath A.J.A., Collins C.M., Cunningham C.O. 2001: Molecular markers for gyrodactylids (Gyrodactylidae: Monogenea) from five fish families (Teleostei). Int. J. Parasitol. 31: 738-745.

Matějusová I., Gelnar M., Verneau O., Cunningham C.O., LitTLEwood D.T.J. 2003: Molecular phylogenies analysis of the genus Gyrodactylus (Platyhelminthes: Monogenea) inferred from rDNA ITS region: subgenera versus species groups. Parasitology 127: 603-611.
Paladini G., Cable J., Fioravanti M.L., Faria P.J., Di Cave D., Shinn A.P. 2009b: Gyrodactylus orecchiae sp. n. (Monogenea: Gyrodactylidae) from farmed population of gilthead seabream (Sparus aurata) in the Adriatic Sea. Folia Parasitol. 56: 21-28.

Paladini G., Gustinelli A., Fioravanti M.L., Hansen H., Shinn A.P. 2009a: The first report of Gyrodactylus salaris Malmberg, 1957 (Platyhelminthes, Monogenea) on Italian cultured stocks of rainbow trout (Oncorhynchus mykiss Walbaum). Vet. Parasitol. 165: 290-297.

Shinn A.P., Des Clers S.A., Gibson D.I., Sommerville C. 1996: Multivariate analysis of morphometrical features from Gyrodactylus spp. (Monogenea) parasitising British salmonids: Light microscope based studies. Syst. Parasitol. 33: 115-125.

Shinn A.P., Hansen H., Olstad K., Bachmann L., Bakke T.A. 2004: The use of morphometric characters to discriminate species of laboratory-reared and wild populations of Gyrodactylus salaris and G. thymalli (Monogenea). Folia Parasitol. 51: 239-252.

Tamura K., Dudley J., Nei M., Kumar S. 2007: MEGA4: Molecular Evolutionary Genetics Analysis (MEGA) software version 4.0. Mol. Biol. Evol. 24: 1596-1599.

Vaughan D.B., Christison K.W., Hansen H., Shinn A.P. 2010: Gyrodactylus eyipayipi sp. n. (Monogenea: Gyrodactylidae) from Syngnathus acus (Syngnathidae) from South Africa. Folia Parasitol. 57: 11-15.

Williams S.R., Kritsky D.C., Dunnigan B., Lash R., Klein P. 2008: Gyrodactylus pisculentus sp. n. (Monogenoidea: Gyrodactylidae) associated with mortality of northern pipefish, Syngnathus fuscus (Syngnathiformes: Syngnathidae) at the Woods Hole Science Aquarium. Folia Parasitol. 55: 265-269.

Ziętara M.S., Huyse T., Lumme J., Volckaert F.A. 2002: Deep divergence among subgenera of Gyrodactylus inferred from rDNA ITS region. Parasitology 124: 39-52.

Ziętara M.S., Lumme J. 2004: Comparison of molecular phylogeny and morphological systematics in fish parasite genus Gyrodactylus Nordmann, 1832 (Monogenea, Gyrodactylidae). Zool. Pol. 49: 5-28.

Accepted 29 January 2010 